\title{
Pengaruh Model Pembelajaran Matematika, Media Jaring-jaring Terhadap Kemampuan Pemecahan Masalah
}

\author{
Nurul Hikmah
}

Pendidikan Matematika, Universitas Indraprasta PGRI

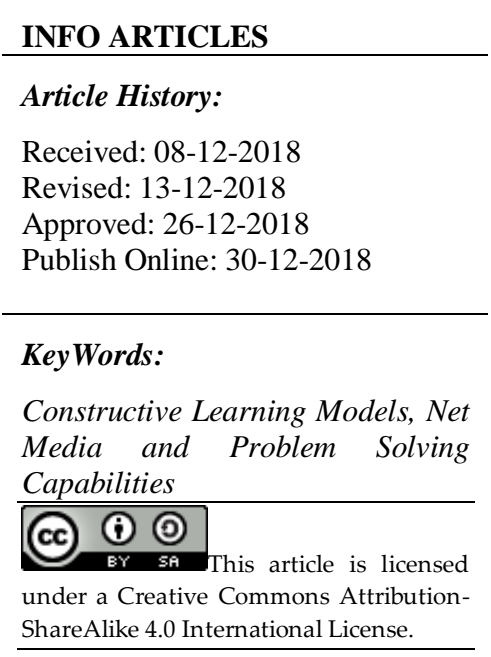

\begin{abstract}
The purpose of this study was to determine the effect of constructive learning models on mathematics subjects, the benefits of net media on cube and beam material, students 'problem solving abilities on cube and beam material and the influence of constructive approaches and net media on students' problem solving abilities in cube and beam material in class VIII. The method used in this study is an experimental method that aims to determine the effect of each variable. This study also uses quantitative methods with statistical calculations to get the right and definite results. The results of data analysis using the t test are as follows tcount> t table ie $(0.146>5.25)$ then HO is rejected. This means that there is the influence of constructive learning models and net media on students' mathematical problem solving abilities.
\end{abstract}

\begin{abstract}
Abstrak: Tujuan dari penelitian ini adalah untuk mengetahui pengaruh model pembelajaran konstruktif pada mata pelajaran matematika, manfaat media bersih pada materi kubus dan balok, kemampuan pemecahan masalah siswa pada materi kubus dan balok dan pengaruh pendekatan konstruktif dan media bersih pada siswa Kemampuan pemecahan masalah dalam bahan kubus dan balok di kelas VIII. Metode yang digunakan dalam penelitian ini adalah metode eksperimen yang bertujuan untuk mengetahui pengaruh masing-masing variabel. Penelitian ini juga menggunakan metode kuantitatif dengan perhitungan statistik untuk mendapatkan hasil yang benar dan pasti. Hasil analisis data menggunakan uji $t$ adalah sebagai berikut thitung $>$ ttabel yaitu $(0,146>5,25)$ maka H0 ditolak. Ini berarti bahwa ada pengaruh model pembelajaran konstruktif dan media bersih terhadap kemampuan pemecahan masalah matematika siswa.
\end{abstract}

Correspondence Address:Jl. Raya Tengah No 80, Jakarta Timur, Indonesia; e-mail: Nurulshauza@ yahoo.co.id

How to Cite (APA $6^{\text {th }}$ Style): Hikmah. (2018). Pengaruh Model Pembelajaran Matematika, Media Jaring-jaring Terhadap Kemampuan Pemecahan Masalah. JKPM (JurnalKajianPendidikanMatematika), Vol.4 (1), 61-66.

Copyright:Nurul Hikmah, (2018)

Competing Interests Disclosures: The authors declare that they have no significant competing financial, professional or personal interests that might have influenced the performance or presentation of the work described in this manuscript. 


\section{PENDAHULUAN}

Matematika merupakan induk ilmu pengetahuan. Namun bukan rahasia lagi bahwa pelajaran matematika kurang diminati oleh kebanyakan siswa karena dianggap sulit. Hal tersebut dikarenakan bahwa di dalam benak para siswa, matematika terdiri atas rumus yang harus dihafal dan dituntut untuk cepat dalam mengerjakan soal. Di sinilah letak tantangan bagi para guru untuk dapat mengubah pandangan para siswa agar matematika dapat menjadi pelajaran favorit. Guru dapat menggali informasi tentang berbagai teknik atau pendekatan yang dapat membantu siswa dalam menguasai permasalahan atau soal dalam pelajaran matematika. Salah satu pendekatan yang dapat digunakan adalah pendekatan konstruktif. Pendekatan pembelajaran konstruktif membangun pemahaman siswa sendiri dari pengalaman baru berdasar pada pengetahuan awal siswa sebelumnya. Pembelajaran harus dikemas menjadi proses mengkonstruksi bukan menerima pengetahuan, pembelajaran melibatkan siswa aktif untuk mengkonstruksi pengetahuannya sendiri melalui interaksi dengan benda konkrit. Melalui kegiatan atau aktivitas inilah siswa membangun pengetahuannya sendiri.Matematika mempunyai peranan penting dalam pendidikan dan teknologi .Matematika sering dipandang sebagai alat mencari solusi dalam berbagai masalah dikehidupan sehari-hari. Melihat pentingnya peranan matematika dalam kehidupan sehari-hari, maka proses pembelajaran matematika harus diperhatikan. Belajar matematika dikatakan berhasil apabila kegiatan pembelajaran matematika berjalan dengan baik.

Salah satu pendekatan pembelajaran pada pelajaran matematika yaitu pendekatan konstruktif. Menurut Suyono dan Hariyanto (2011:106), pendekatan konstruktif adalah suatu pendekatan yang mengkontruksi sendiri realitasnya yang berlandaskan persepsi tentang pengalamannya. Sehingga pengetahuan individu adalah sebuah fungsi dari pengalaman sebelumnya, juga struktur mentalnya, yang kemudian digunakan untuk menerjemahkan objek-objek serta kejadian-kejadian baru. Berdasarkan kutipan teori di atas, maka dapat disimpulkan bahwa pendekatan konstruktif adalah suatu metode yang membuat siswa membuat sudut pandangnya sendiri dalam memahami sebuah masalah dalam hal ini soal dalam pembelajaran matematika dengan topik kubus dan balok. Guru diharapkan tidak hanya memberikan rumus kepada siswanya namun memberikan konsep yang mudah dipahami oleh para siswa sehingga siswa dapat menggunakan imajinasinya atau pengalaman yang ada pada dirinya dalam menggambarkan penyelesaian terhadap masalah atau soal yang harus diselesaikan atau dikerjakan.

Dalam pembelajaran matematika siswa tidak hanya dituntut untuk mampu mendengarkan dan menghafal materi, tetapi siswa diharapkan mampu untuk memahami konsep-konsep matematika. Pentingnya pemahaman konsep matematika dapat dilihat dari tujuan pembelajaran matematika Peraturan Menteri Pendidikan Nasional Nomor 22 tahun 2006, yaitu memahami konsep matematika, menjelaskan ketertakaitan antar konsep dan mengaplikasikan konsep atau logartima, secara luwes, akurat, efisien dan tepat dalam pemecahan masalah. Menurut Turmudi (2008:24), pemecahan masalah adalah proses melibatkan suatu tugas yang metode pemecahannya belum diketahui lebih dahulu. Berdasarkan kutipan teori di atas, maka dapat disimpulkan bahwa pemecahan masalah adalah sebuah proses melalui tugas yang diberikan oleh siswa untuk dicari solusi (jawaban) yang tepat.

Menurut Wolfolk (dalam Uno, 2011:134) kemampuan pemecahan masalah adalah suatu keterampilan seorang siswa dalam menggunakan proses berpikirnya untuk memecahkan masalah melalui pengumpulan fakta, analisis informasi, menyususn berbagai alternatif pemecahan dan memilih pemecahan yang paling efektif. Berdasarkan teori-teori di atas, maka dapat disimpulkan bahwa kemampuan pemecahan masalah adalah kemampuan atau keterampilan yang dimiliki oleh siswa dalam memahami soal (permasalah), menentukan rumus atau jawaban yang tepat serta menemukan langkah-langkah lain atau alternatif apabila cara yang digunakan sebelumnya tidak berhasil menjawab soal yang diberikan kepadanya. 
Pembelajaran matematika di kelas VIII pada SMP sudah menggunakan alat peraga sebagai media yang memberikan pengalaman langsung kepada siswa dalam belajar. Menurut Daryanto (2010:157) mengungkapkan bahwa media adalah segala sesuatu yang dapat digunakan untuk menyalurkan pesan dari pengirim ke penerima sehingga dapat merangsang pikiran, perasaan, perhatian dan minat serta perhatian siswa sedemikian rupa sehingga proses belajar mengajar terjadi. Menurut Yunus dalam Arsyad (2010:16) belajar dengan menggunakan media, dalam hal ini media visual, hasilnya tidak sama dengan belajar tanpa media. Salah satu media belajar yaitu jaring-jaring bangun ruang merupakan sebuah media untuk membuat sebuah bangun. Gambar jaring-jaring sebuah bangun dibentuk sesuai dengan bangun yang akan dibuat jadi masing-masing bangun memiliki bentuk jaring-jaringnya masing-masing.

Berdasarkan pendapat di atas, maka media pembelajaran adalah media memiliki manfaat yang cukup besar untuk membantu guru dalam menyampaikan materi agar menarik perhatian siswa sehingga siswa dapat memperhatikan dengan sungguh-sungguh hal-hal yang disampaikan oleh guru dan mendapatkan pemahaman yang membuat mereka mendapatkan pengalaman dan pengetahuan baru. salah satunya adalah membuat jaring-jaring kubus dan balok. Sesuai dengan materi yang sedang dipelajari oleh siswa. Penggunaan media dan model pembelajaran konstrutif saling berkaitan, yaitu memberikan peserta didik pengalaman dalam proses pembelajaran dan untuk berpikir dalam memecahkan permasalahan yang tergambar melalui soal-soal dalam materi kubus dan balok.

Matematika penting untuk diajarkan pada siswa di sekolah. Hal ini ditegaskan dalam UndangUndang RI Nomor 20 Tahun 2003 tentang Sistem Pendidikan Nasional yang menyebutkan bahwa mata pelajaran matematika merupakan salah satu mata pelajaran wajib bagi siswa pada jenjang pendidikan dasar dan menengah. Adapun tujuan pembelajaran matematika dijenjang pendidikan dasar dan pendidikan menengah menurut Peraturan Menteri Pendidikan Nasional Nomor 22 Tahun 2006 adalah untuk mempersiapkan siswa agar sanggup menghadapi perubahan keadaan di dalam kehidupan dan di dunia yang selalu berkembang, melalui latihan bertindak atas dasar pemikiran secara logis, rasional, kritis, cermat, jujur, efisien dan efektif. Berdasarkan permasalahan yang ada diatas maka peneliti mengambil judul "Pengaruh Model Pembelajaran Konstruktif dan Media Jaring-jaring terhadap Kemampuan Pemecahan Masalah pada Materi Kubus dan Balok di Kelas VIII SMP”

\section{METODE}

Metode yang digunakan dalam penelitian ini adalah metode eksperimen. Dengan memberikan treatment atau menciptakan sebuah kondisi pada subjek yang diteliti. Kelompok yang satu dijadikan sebagai kelompok eksperimen.

Desain eksperimen yang digunakan pada penelitian ini yaitu Quasi Eksperimen Design, merupakan salah satu desain eksperimen yang memiliki kelompok kontrol tetapi tidak berfungsi sepenuhnya untuk mengontrol variabel-variabel luar yang mempengaruhi pelaksanaan eksperimen(Sugiyono, 2015:2). Penelitian eksperimen ini dilakukan dengan The one short case study, dimana peneliti memberi perlakuan pada dua kelas dengan tingkat kemampuan yang sama dengan bentuk model pembelajaran. Kelas pertama merupakan kelas eksperimen yang mendapat perlakuan pembelajaran matematika dengan menggunakan model pembelajaran problem based learning disertai dengan alat peraga berupa puzzle dadu kemudian diberikan angket minat belajar matematika dan postest berupa soal uraian materi peluang. Pada kelas kedua merupakan kelas kontrol yang mendapat perlakuan pembelajaran matematika dengan model pembelajaran yang sama yaitu problem based learning tanpa disertai alat peraga kemudian diberikan angket minat belajar matematika dan postest berupa soal uraian materi peluang. 
64 Hikmah

Dalam penelitian diambil 56 siswa.Pengambilan sampel pada penelitian ini dilakukan dengan langkah sampling. Sumber data dalam penelitian ini diperoleh dari post test. Nilai post test dijadikan sebagai data. Mengingat model pembelajaran Konstruktif dan media jaring-jaring dapat dilihat berdasarkan pengaruhnya terhadap respon siswa dalam mengaplikasikan pada kemampuan mereka dalam menyelesaikan soal pada materi kubus dan balok.

\section{HASIL}

Hasil perhitungan deskriptif dapat digambarkan melalui tabel 1.

Tabel 1. Perbandingan Pemecahan masalah Kelas Eksperimen dan Kelas Kontrol

\begin{tabular}{ccc}
\hline Statistik & Kelas Eksperimen & Kelas Kontrol \\
\hline Nilai Terendah & 70 & 50 \\
Nilai Tertinggi & 90 & 70 \\
Mean & 81,57 & 62,10 \\
Median & 64,40 & $-20,25$ \\
Modus & 60,33 & 17,62 \\
\hline
\end{tabular}

Uji persayaratan yang digunakan untuk menganalisis data tes pemahaman konsep matematika siswa adalah uji perbedaan dua rata-rata. Uji perbedaan dua rata-rata yang akan digunakan adalah uji $t$. Akan tetapi uji $t$ dapat digunakan apabila memenuhi asumsi atau persyaratan yaitu:

1. Sampel berasal dari data yang berdistribusi normal. Hal ini dapat diketahui dengan melakukan uji normalitas.

2. Varians kedua populasi homogen. Hal ini dapat diketahui dengan melakukan uji homogenitas.

Untuk lebih jelasnya, hasil dari uji normalitas antara kelas eksperimen dan kelas kontrol dapat dilihat pada tabel 2. 
Tabel 2. Hasil Uji Normalitas dan Homogenitas

\begin{tabular}{|c|c|c|c|c|c|}
\hline Kelas & $N$ & $\alpha$ & $\mathbf{L}^{\text {hitung }}$ & $\begin{array}{l}\mathbf{L} \quad \text { tabel } \\
\alpha=0,05\end{array}$ & Kesimpulan \\
\hline Eksperimen & 28 & $5 \%$ & 0,020 & 0,161 & \multirow{2}{*}{$\begin{array}{c}\text { Kedua kelas } \\
\text { berdistribusi } \\
\text { normal }\end{array}$} \\
\hline Kontrol & 28 & $5 \%$ & 0,020 & 0,161 & \\
\hline
\end{tabular}

Setelah kedua kelas sampel pada penelitian ini dinyatakan berasal dari populasi yang berdistribusi normal, maka selanjutnya dilakukan uji homogenitas varians kedua populasi tersebut dengan menggunakan uji F. Uji homogenitas ini dilakukan untuk mengetahui apakah kedua varians populasi homogen.

$$
\begin{aligned}
\mathrm{F}_{\text {hitung }} & =\frac{\text { varians terbesar }}{\text { varians terkecil }} \\
& =1,07
\end{aligned}
$$

Dari hasil di atas, diperoleh nilai $F_{\text {hitung }}=1,07$ sedangkan $F_{\text {tabel }}$ dicari dengan $\left(\alpha, \mathrm{dk}_{2}, \mathrm{dk}_{1}\right),=1,88$. Oleh karena itu, $F_{\text {hitung }}$ kurang dari $\mathrm{F}_{\text {tabel }}(1,07<1,88)$ artinya $\mathrm{H}_{0}$ diterima sehingga dapat disimpulkan bahwa kedua data memiliki varians yang homogen.

Setelah dilakukan uji persyaratan analisis data, diperoleh bahwa kedua kelompok berdistribusi normal dan homogen. Selanjutnya, akan dilakukan uji hipotesis penelitian menggunakan uji t dengan kriteria sebagai berikut:

Jika $t_{\text {hitung }}<\mathrm{t}_{\text {tabel }}$ maka terima $\mathrm{H}_{0}$

Jika $t_{\text {hitung }}>\mathrm{t}_{\text {tabel }}$ maka tolak $\mathrm{H}_{0}$

Pasangan hipotesis statistik yang akan diuji adalah sebagai berikut:

$H_{0}: \mu_{1} \leq \mu_{2}$

$H_{1}: \mu_{1}>\mu_{2}$

Keterangan :

$\mu_{1}$ : Rata-rata hasil belajar matematika kelompok eksperimen

$\mu_{2}$ : Rata-rata hasil belajar matematika kelompok kontrol

\section{PEMBAHASAN}

Berdasarkan hasil perhitungan uji $t$ tersebut membuktikan bahwat ${ }_{\text {hitung }}>\mathrm{t}_{\text {tabel }}$ yaitu 5,25 $>0,146$. Ini menyimpulkan bahwa $\mathrm{H}_{0}$ ditolak atau menerima $\mathrm{H}_{1}$, dengan demikian dapat ditarik kesimpulan bahwa ada perbedaan kemampuan pemecahan masalah matematika siswa pada materi kubus dan balok yang menggunakan model pembelajaran konstruktif(kelas eksperimen) dengan metode cermah (kelas kontrol). Dapat di simpulkan bahwa dalam penelitian ini, metode pembelajaran konstruktiflebih baik dari metode ceramah.

Pembelajaran yang monoton dapat menyebabkan kebosanan pada siswa.Untuk lebih memotivasi dan menghindari kebosanan pada siswa dalam pelaksanaan pembelajaran, guru dapat melakuakan variasi dalam pembelajaran yang menyenangkan dan membangkitkan minat siswa. Penerapan metode yang tepat dapat 
memotivasi siswa agar lebih aktif dan menemukan sendiri materi yang akan diberikan sehingga siswa dapat memahami kemampuan pemecahan masalah itu sendiri. Selain itu, guru dapat memberikan kesempatan kepada siswa untuk mengembangkan serta menggali kemampuan siswa.Melalui metode ini siswa dapat bertukar pendapat dengan teman kelompok untuk memahami dan memecahan masalah matematika.Dengan demikian siswa perlu memahami konsep - konsep matematika untuk menarik suatu kesimpulan.

\section{SIMPULAN}

Berdasarkan hasil penelitian dan pengujian hipotesis dapat disimpulkan bahwa model pembelajaran konstruktif berpengaruh terhadap kemampuan pemecahan masalah siswa kelas VIII pada materi kubus dan balok. Hal ini karena pemberian model pembelajaran konstruktifmerupakan salah satu cara yang dapat menumbuhkan kemandirian siswa dalam berpikir dan menemukan berbagai alternatif dalam menemukan jawaban dari soal-soal atau tugas yang diberikan oleh guru. Dengan modal kemandirian dalam berpikir, diharapkan siswa dapat terus bersemangat dan tidak mudah putus asa saat menghadapi masalah.

\section{DAFTAR RUJUKAN}

Arsyad, Azhar. 2010. Media Pembelajaran. Jakarta: PT Raja Grafindo Persada

Daryanto. 2010. Media Pembelajaran. Yogyakarta: Gava Media.

Hamzah B. Uno. 2011. Teori Motivasi dan Pengukurannya: Analisis di Bidang Pendidikan. Jakarta: Bumi aksara.

Suyono dan Hariyanto. 2011. Belajar dan Pembelajaran. Teori dan Konsep Dasar. Surabaya: Rosda

Sugiyono.2015.Metode penelitian pendidikan pendekatan kuantitatif, kualitatif,dan $R \& D$.Bandung:Alfabeta

Turmudi. 2008. Landasan Filsafat dan Teori Pembelajaran Matematika(Berparadigma Eksploratif dan Investigatif). Jakarta: Leuser Cipta Pustaka. 